\title{
Article \\ Effect of the Glycine Treatment on Synthesis and Physicochemical Characteristics of Nanosized Ni-Mn Mixed Oxides
}

\author{
Ghadah M. Al-Senani ${ }^{1}{ }^{(D}$, Omar H. Abd-Elkader ${ }^{2,3, *}{ }^{\mathbb{C}}$, Nada S. Al-Kadhi ${ }^{1}$ and Nasrallah M. Deraz ${ }^{4}$ \\ 1 Department of Chemistry, College of Science, Princess Nourah Bint Abdulrahman University, P.O. Box 84428, \\ Riyadh 11671, Saudi Arabia; gmalsnany@pnu.edu.sa (G.M.A.-S.); nsalkadhi@pnu.edu.sa (N.S.A.-K.) \\ 2 Physics and Astronomy Department, Science College, King Saud University, P.O. Box 2455, \\ Riyadh 11451, Saudi Arabia \\ 3 Physics Division, Electron Microscope and Thin Films Department, National Research Centre, El Behooth St., \\ Giza 12622, Egypt \\ 4 Physical Chemistry Department, National Research Centre, Dokki, El Behooth St., Giza 12622, Egypt; \\ amn341@yahoo.com \\ * Correspondence: omabdelkader7@ksu.edu.sa
}

check for updates

Citation: Al-Senani, G.M.; Abd-Elkader, O.H.; Al-Kadhi, N.S.; Deraz, N.M. Effect of the Glycine Treatment on Synthesis and Physicochemical Characteristics of Nanosized Ni-Mn Mixed Oxides. Crystals 2021, 11, 487. https:// doi.org/10.3390/cryst11050487

Academic Editors: Assem Barakat and Alexander S. Novikov

Received: 20 March 2021

Accepted: 22 April 2021

Published: 26 April 2021

Publisher's Note: MDPI stays neutral with regard to jurisdictional claims in published maps and institutional affiliations.

Copyright: (c) 2021 by the authors. Licensee MDPI, Basel, Switzerland. This article is an open access article distributed under the terms and conditions of the Creative Commons Attribution (CC BY) license (https:/ / creativecommons.org/licenses/by/ $4.0 /)$.

\begin{abstract}
Magnetic Ni-Mn mixed oxides based on nanoparticles (NPs) have been developed at $700{ }^{\circ} \mathrm{C}$ using a ceramic method and a glycine-assisted auto combustion path. The thermogravimetryderivative thermogravimetry (TG-DTG), infrared radiation (IR), X-ray powder diffraction (XRD), energy-dispersive X-ray spectroscopy (EDX) and high resolution transmittance electron micrographs (HRTEM) techniques have been used to characterize as synthesized nanomaterials by evaluating their thermal behavior, structure, distinguishing the components and establishing the morphology. A vibrating sample magnetometer has been used to estimate the magnetic properties of the materials (VSM). The analyses indicate that using a glycine-assisted auto combustion method resulted in formation of cubic spinel $\mathrm{NiMn}_{2} \mathrm{O}_{4} \mathrm{NPs}$ as a single phase. The ceramic process, from the other side, led to the development of $\mathrm{Mn}_{2} \mathrm{O}_{3} / \mathrm{NiMnO}_{3} / \mathrm{NiMn}_{2} \mathrm{O}_{4}$ nanocomposite. The resulting particles being polycrystalline, including average sizes ranging from 10 to 80 nanometers. The prepared $\mathrm{NiMn}_{2} \mathrm{O}_{4}$ NPs showed room-temperature ferromagnetism, with an optimal saturation magnetization value of $5.0216 \mathrm{emu} / \mathrm{g}$, according to the magnetic measurement.
\end{abstract}

Keywords: $\mathrm{NiMn}_{2} \mathrm{O}_{4}$ nanoparticles; TG-DTG; IR; XRD; HRTEM; EDX; VSM

\section{Introduction}

Most mixed transition metal oxides-based nanomaterials have recently evoked strong interest in various structures with stoichiometric or even non-stoichiometric compositions. However, the interest in nanoparticle physics has increased markedly because its physical and chemical properties differ compared to the corresponding bulk ones. These materials display a vast range of fascinating electrical, surface, catalytic and magnetic properties which often come about due to the mixed valence states of these oxides. The combined oxides with the defined structure perform better than its two single-component oxides in terms of cost, stability, toxicity, natural abundance and easy preparation. Plenty of spinel $\mathrm{AB}_{2} \mathrm{O}_{4}$ compounds, including ferrites of $\mathrm{MFe}_{2} \mathrm{O}_{4}$, cobaltites of $\mathrm{MCo}_{2} \mathrm{O}_{4}$, and aluminates of $\mathrm{MAl}_{2} \mathrm{O}_{4},(\mathrm{M}=\mathrm{Cu}, \mathrm{Mn}, \mathrm{Ni}$ and $\mathrm{Zn})$ with various morphologies have been extensively investigated in recent years $[1,2] . \mathrm{A}^{2+}$ and $\mathrm{B}^{3+}$ cations occupy a section including all of the tetrahedral and octahedral sites, respectively, in these compounds, which have been developed around a dense array of $\mathrm{O}^{2-}$ ions. Furthermore, the abundance of cationic holes improves not only the electric conductivity but also the magnetic activity by providing more active sites for catalytic processes [3]. More importantly, the solid-state redox couples 
of $\mathrm{A}^{3+} / \mathrm{A}^{2+}$, and $\mathrm{B}^{3+} / \mathrm{B}^{2+}$ in this structure enable the spinel oxides to exhibit a remarkable activity towards various applications [4].

Manganese oxide-based materials have a variety of structures, such as perovskites, spinels or pyrochlores as manganites, depending on the variable oxidation states and different manganese coordinations. Manganites have such a broad range of specific electrical and magnetic properties as a result of these discoveries, including colossal magnetoresistance, ferromagnetism, charge ordering and several others $[5,6]$. Nickel manganite crystallizes in a partially inverse cubic spinel structure where nickel and manganese ions are distributed among the tetrahedral and octahedral sites [7]. In many other terms, $\mathrm{NiMn}_{2} \mathrm{O}_{4}$ spinel is slightly inverted rather than normal. Furthermore, minor polaron hopping between $\mathrm{Mn}^{3+}$ and $\mathrm{Mn}^{4+}$ cations will be used to achieve electron transport in this manganite [8]. These merits promise improved performance of spinel $\mathrm{NiMn}_{2} \mathrm{O}_{4}$. This is due to specific atomic substitute in the $\mathrm{NiMn}_{2} \mathrm{O}_{4}$ lattice caused by re-arrangement of $\mathrm{Ni}$ and $\mathrm{Mn}$ ions according to their identical chemical states and ionic radii, leading to decreased lattice constant [9]. Evidently, a minority of $\mathrm{Ni}^{2+}$ cations migrate from tetrahedral to octahedral interstices of its oxygen face centered cubic sublattice, with a corresponding proportion of $\mathrm{Mn}^{3+}$ cations on octahedral sites transformed to $\mathrm{Mn}^{2+}$ and $\mathrm{Mn}^{4+}$, and subsequent migration of $\mathrm{Mn}^{2+}$ cations to tetrahedral sites to accommodate for $\mathrm{Ni}^{2+}$ vacancies [10]. This process is dependent on the sintering history of the sample. However, the sintering history also affects the oxygen stoichiometry, which again changes the $\mathrm{Mn}^{3+} / \mathrm{Mn}^{4+}$ ratio $[10,11]$.

The distribution of cations in spinel type structure is suggested to impact the essential structural, electrical, and magnetic properties of manganite spinel, which lead to their applications in a number of environments. Negative-temperature coefficient (NTC) thermistors, catalysts, sensors, Li-ion batteries, electrochemical supercapacitors, and prospective spintronic devices are using spinel nickel manganites materials [12-17]. Nickel manganite can be prepared by different methods such as solid-state reaction between $\mathrm{Ni}$ and Mn oxides, sol-gel and as well as auto-combustion [18-21]. The auto-combustion technique is one of the preferred methods for preparing the nanosized manganites. The auto-combustion resulted in the reduction in exothermicity and the augmentation in the number of gaseous products which dissipate the heat.

The purpose of this research is to make a comparison between two different methods for preparation of nickel manganites, namely glycine assisted auto-combustion method and conventional ceramic method. Various techniques were used to characterize the prepared materials. The magnetic properties of the solids as prepared were determined.

\section{Materials and Methods}

\subsection{Materials}

Nickel (II) nitrate hexahydrate, manganese (II) nitrate hydrate and glycine were purchased from Sigma-Aldrich Company (Darmstadt, Taufkirchen, Germany). The linear formula of the previous materials was $\mathrm{Ni}\left(\mathrm{NO}_{3}\right)_{2} \cdot 6 \mathrm{H}_{2} \mathrm{O}, \mathrm{Mn}\left(\mathrm{NO}_{3}\right)_{2} \cdot 4 \mathrm{H}_{2} \mathrm{O}$ and $\mathrm{NH}_{2} \mathrm{CH}_{2}$ $\mathrm{COOH}$, respectively.

\subsection{Preparation Method}

Two samples of nickel-manganese oxides were synthesized by mixing calculated proportions of $(2.91 \mathrm{~g})$ nickel and $(5.05 \mathrm{~g})$ manganese nitrates without and with a certain amount $(4 \mathrm{~g})$ of glycine as fuel. The mixture of these precursors was concentrated in a glass beaker $(500 \mathrm{~mL})$ by heating it at $300{ }^{\circ} \mathrm{C}$ for $10 \mathrm{~min}$ on a hot plate. The crystallization and physisorbed water were gradually vaporized during the heating. In presence of glycine, when the beaker temperature reached $300{ }^{\circ} \mathrm{C}$, a great deal of foam was produced, with a subsequent spark that appeared in one corner and spread through the mass. Finally, a voluminous and fluffy black product was produced in the container. In absence of glycine, the previous observation does not occur, but when the beaker temperature reached $300{ }^{\circ} \mathrm{C}$, black condensed powder was formed as a final product. The final products were calcined 
in air at $700{ }^{\circ} \mathrm{C}$ for $2 \mathrm{~h}$ to obtain the S1 sample in case of the ceramic method and also the S2 sample in the case of glycine-assisted auto-combustion method.

\subsection{Characterization Techniques}

A thermal analyzer, the Nietzsche 449 Jupiter design (Weimar, Döbereiner, Germany) has been used to acquire simultaneous thermogravimetry-derivative thermogravimetry (TG-DTG) measurements. The investigations were performed under a nitrogen gas atmosphere in a temperature range of $25-1000{ }^{\circ} \mathrm{C}$ at a gas flow rate of $40 \mathrm{~mL} \mathrm{~min}{ }^{-1}$. The rate of heating of the test sample was $10^{\circ} \mathrm{C} \mathrm{min}^{-1}$.

The X-ray measurements of different mixed solids were performed using a BRUKER D8 advanced diffractometer (Bruker, Karlsruhe, Germany). $\mathrm{Cu} \mathrm{K} \alpha \mathrm{X}$ ray radiation at $40 \mathrm{kV}, 40 \mathrm{~mA}$ with a $2 \Theta$ scanning speed of $2^{\circ} \mathrm{min}^{-1}$ has been used to generate the X-ray diffraction patterns.

The Scherrer equation was used to determine the crystallite sizes of the crystalline products thru the X-ray diffraction-line broadening [22].

$$
d=\frac{B \lambda}{\beta \cos \theta}
$$

$\mathrm{d}=$ average crystallite size of the phase under investigation,

$\mathrm{B}=$ Scherrer constant (0.89),

$\lambda=$ wavelength of the $\mathrm{X}$-ray beam used,

$\beta=$ full-width half maximum (FWHM) of diffraction line, and

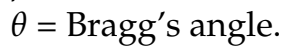

An infrared transmission spectrum of various solids was determined using PerkinElmer Spectrophotometer (type 1430). The IR spectra were determined from 4000 to $400 \mathrm{~cm}^{-1}$. Two $\mathrm{mg}$ of each solid sample were mixed with $200 \mathrm{mg}$ of vacuum-dried IRgrade $\mathrm{KBr}$. The mixture was dispersed by grinding for $3 \mathrm{~min}$ in a vibratory ball mill and placed in a steel die $13 \mathrm{~mm}$ in diameter and subjected to a pressure of 12 tons. The sample disks were placed in the holder of the double grating IR spectrometer.

High resolution transmittance electron micrographs (HRTEM) were recorded on a JEOL, JEM 2100 HRT (JEOL, Tokyo, Japan) electron micro-analyzer. The parameters were as follows: Accelerating voltage $=200 \mathrm{KV}$, Resolution $=0.2 \mathrm{~nm}$, High Mag $=2000$ to $1 \mathrm{MX}$, Low Mag $=50$ to $6000 \times$. A small drop of ultrasonically prepared ethanol colloidal suspension (usually around $5 \mu \mathrm{L}$ ) was pipetted onto a carbon coated copper TEM grid and left to dry at room temperature. After the medium had evaporated, the grid was seen directly in a TEM.

On a JEOL, JED-2200 Series (JEOL, Tokyo, Japan) scanning electron microscope with an attached Kevex Delta system, the energy-dispersive X-ray analysis (EDX) data was captured. The parameters were as follows: accelerating voltage, $15 \mathrm{kV}$; accumulation time, $100 \mathrm{~s}$; and window width, $8 \mathrm{~mm}$. The surface molar composition was determined by the Asa method, with ZAF correction and Gaussian approximation.

A vibrating sample magnetometer (9600-1 LDJ, Weistron Co., Ltd., West Hollywood, CA, USA) had been used to measure the magnetic properties of the examined solids at room temperature in a measured maximum field of $20 \mathrm{kOe}$. The saturation magnetization $\left(M_{s}\right)$, remanence magnetization $\left(M_{r}\right)$, coercivity $\left(H_{c}\right)$, squareness $\left(M_{r} / M_{s}\right)$ and anisotropy constant $\left(\mathrm{K}_{\mathrm{a}}\right)$ had been evaluated using the hysteresis loops obtained.

\section{Results}

\subsection{TG/DTG Analyses}

The S1 sample was exposed to the heat treatment in order to ascertain its heat stability and to understand its degradation pattern. TG-DTG measurements were used to study the thermal characteristics for the S1 sample as illustrated in Figure 1. 


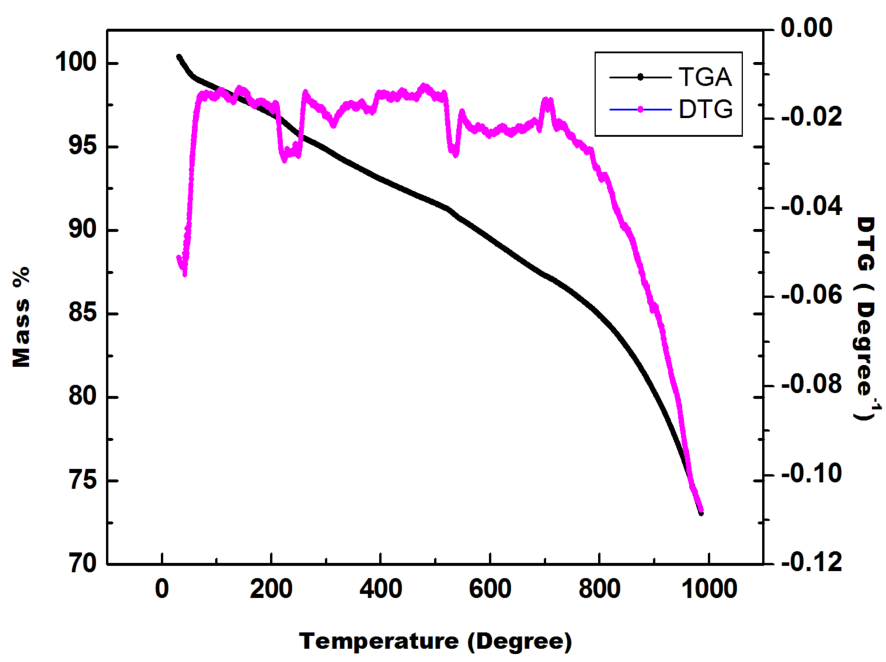

Figure 1. TG-DTG pattern of the S1 sample.

DTG thermogram of the S1 specimen shows endothermic peak located at $50{ }^{\circ} \mathrm{C}$. This peak was followed by $\sim 1.1 \%$ weight loss as a result of desorption or removal of moisture. The DTG peaks were observed at $250{ }^{\circ} \mathrm{C}, 325^{\circ} \mathrm{C}$ and $430{ }^{\circ} \mathrm{C}$ with weight loss $\sim 7.7 \%$ which corresponds to the complete formation of $\mathrm{Mn}_{2} \mathrm{O}_{3}$ and $\mathrm{NiMnO}_{3}$. The formation process of this composite may be expressed as:

$$
\begin{gathered}
2 \mathrm{Ni}\left(\mathrm{NO}_{3}\right)_{2} \cdot 6 \mathrm{H}_{2} \mathrm{O}+4 \mathrm{Mn}\left(\mathrm{NO}_{3}\right)_{2} \cdot 4 \mathrm{H}_{2} \mathrm{O} \rightarrow \mathrm{Mn}_{2} \mathrm{O}_{3}+2 \mathrm{NiMnO}_{3}+12 \mathrm{NO}_{2}+1.5 \mathrm{O}_{2} \\
+28 \mathrm{H}_{2} \mathrm{O}
\end{gathered}
$$

Further DTG peak was located at $525{ }^{\circ} \mathrm{C}$ with weight loss $\sim 8.3 \%$. This weight loss could be due to partially solid-state reaction between the thermal products of the mixed oxides $\left(\mathrm{Mn}_{2} \mathrm{O}_{3}\right.$ and $\left.\mathrm{NiMnO}_{3}\right)$ and/or phase transformation process yielding an excess amount of $\mathrm{NiMn}_{2} \mathrm{O}_{4}$ with liberation of oxygen according to the following reaction [23]:

$$
\mathrm{Mn}_{2} \mathrm{O}_{3}+2 \mathrm{NiMnO}_{3} \rightarrow 2 \mathrm{NiMn}_{2} \mathrm{O}_{4}+0.5 \mathrm{O}_{2}
$$

To the alternative, the weight loss (9.3\%) in the range between $850-1000{ }^{\circ} \mathrm{C}$ could be due to the complete transformation of $\mathrm{Mn}_{2} \mathrm{O}_{3}$ and $\mathrm{NiMnO}_{3}$ to $\mathrm{NiMn}_{2} \mathrm{O}_{4}$. Indeed, the value of the theoretical mass loss for the synthesized mixed oxides was $26.4 \%$. This value is close to those found experimentally (27.35\%). Thus, $\mathrm{Mn}_{2} \mathrm{O}_{3} / \mathrm{NiMnO}_{3} / \mathrm{NiMn}_{2} \mathrm{O}_{4}$ and $\mathrm{NiMn}_{2} \mathrm{O}_{4}$ hybrid nano particles can be synthesized by ceramic method in the thermal range of $450-850{ }^{\circ} \mathrm{C}$ and $850-1000{ }^{\circ} \mathrm{C}$, respectively [21]. Similar results were reported in our previous work on the production of spinel $\mathrm{NiMn}_{2} \mathrm{O}_{4} \mathrm{NPs}$ by adding calculated amounts of both nickel and manganese nitrates with and without a certain amount of egg white, immediately heated at $950{ }^{\circ} \mathrm{C}$ in air for $2 \mathrm{~h} \mathrm{[21].}$

In continuation of our previous work, we seek in this study to decrease the preparation temperature of $\mathrm{NiMn}_{2} \mathrm{O}_{4}$ solid by altering the fuel material from egg white to glycine. This is what made us also dealt with the traditional ceramic method for making a comparative study with the combustion method based on glycine. The ceramic method at $450-850{ }^{\circ} \mathrm{C}$ was used to build a composite containing $\mathrm{Mn}_{2} \mathrm{O}_{3} / \mathrm{NiMnO}_{3} / \mathrm{NiMn}_{2} \mathrm{O}_{4} \mathrm{NPs}$ in this sample. XRD analysis will validate this result.

\subsection{XRD Analysis}

The identification and distinction between the crystalline lattices in the as synthesized solids carried out using the XRD analysis. XRD patterns of the S1 and S2 samples calcined at $700{ }^{\circ} \mathrm{C}$ for $2 \mathrm{~h}$ were illustrated in Figure 2, respectively. Examining this figure led to the following results: (i) the existence of $\mathrm{NiMn}_{2} \mathrm{O}_{4}, \mathrm{NiMnO}_{3}$ and $\mathrm{Mn}_{2} \mathrm{O}_{3}$ phases are registered in the XRD pattern of the S1 sample. 


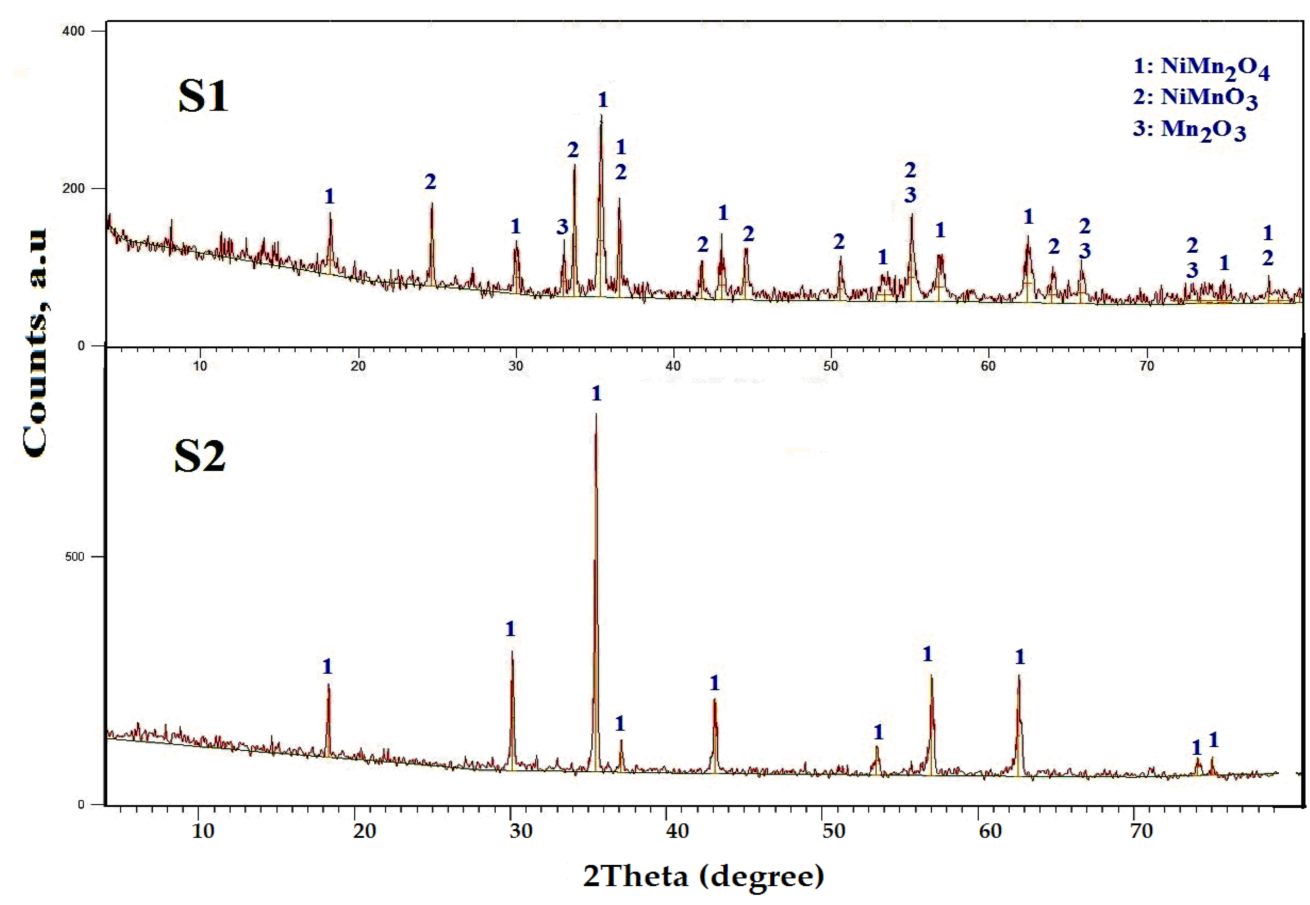

Figure 2. XRD patterns of the $\mathrm{S} 1$ and $\mathrm{S} 2$ samples.

In other words, the hybrid oxides $\left(\mathrm{NiMn}_{2} \mathrm{O}_{4} / \mathrm{NiMnO}_{3} / \mathrm{Mn}_{2} \mathrm{O}_{3}\right)$ rather than singlephase ones can be achieved during pyrolysis of the precursors without glycine at $700{ }^{\circ} \mathrm{C}$. Indeed, XRD analysis of the $\mathrm{S} 1$ sample displays the construction of well crystalline $\mathrm{NiMn}_{2} \mathrm{O}_{4}$ as a major phase with cubic spinel like structure and space group Fd3m (PDF 01-1110). However, the Powder Diffraction File is a structured file that includes inorganic diffraction data for crystals and powders that can be quickly searched for unknown phase recognition. These findings relied on the diffraction lines of $\mathrm{NiMn}_{2} \mathrm{O}_{4}$ own of the families of crystalline planes (111), (220), (311), (222), (400), (422), (511), (440), (533), (622) and (441). However, the peaks own of the families of crystalline planes (012), (104), (110), (113), (202), (024), (116), (214), (300), (119) and (217) belong to $\mathrm{NiMnO}_{3}$ with a rhombohedral structure of the $\mathrm{R} 3$ space group (PDF 12-269) [24]. On the other side, XRD pattern of the $\mathrm{S} 1$ sample displays formation of small amount of moderate crystalline cubic $\mathrm{Mn}_{2} \mathrm{O}_{3}$ lattice with space group $\mathrm{Ia}^{-}$(PDF 41-1442). The peaks of $\mathrm{Mn}_{2} \mathrm{O}_{3}$ were observed with the planes of (222), (440) and (622). (ii) Based on the height of the characteristic diffraction peaks of $\mathrm{NiMn}_{2} \mathrm{O}_{4}$ (311), $\mathrm{NiMnO}_{3}$ (104) and $\mathrm{Mn}_{2} \mathrm{O}_{3}$ (222) planes can be used for calculation of the relative content or the calculated fraction $(\mathrm{F})$ of these phases in the $\mathrm{S} 1$ sample by using the following relation:

$$
\mathrm{F}=\mathrm{I}_{\text {invest }} / \mathrm{I}_{\text {total }}
$$

where $\mathrm{I}_{\text {invest }}$ is the count of $\mathrm{I}_{222}$ or $\mathrm{I}_{311}$ or $\mathrm{I}_{104}$ of the studied phase and $\mathrm{I}_{\text {total }}$ is the sum of the counts of $\mathrm{I}_{222}, \mathrm{I}_{311}$ and $\mathrm{I}_{104}$ of cubic $\mathrm{Mn}_{2} \mathrm{O}_{3}, \mathrm{NiMn}_{2} \mathrm{O}_{4}$ and rhombohedra $\mathrm{NiMnO}_{3}$ phases detected in the XRD pattern, respectively. The fraction of $\mathrm{NiMn}_{2} \mathrm{O}_{4}, \mathrm{NiMnO}_{3}$ and $\mathrm{Mn}_{2} \mathrm{O}_{3}$ phases present in porous $\mathrm{NiMn}_{2} \mathrm{O}_{4} / \mathrm{NiMnO}_{3} / \mathrm{Mn}_{2} \mathrm{O}_{3}$ nanocomposite were found to be $48 \%, 41 \%$ and $12 \%$, respectively. (iii) On other hand, glycine assisted combustion method followed by heating at $700{ }^{\circ} \mathrm{C}$ for $2 \mathrm{~h}$ resulted in solid-solid interaction between $\mathrm{NiMnO}_{3}$ and $\mathrm{Mn}_{2} \mathrm{O}_{3}$ yielding $\mathrm{NiMn}_{2} \mathrm{O}_{4}$. To put it more simply, heat treatment of as synthesized precursors containing a certain amount of glycine at $700{ }^{\circ} \mathrm{C}$ resulted in complete conversion of the investigated materials to $\mathrm{NiMn}_{2} \mathrm{O}_{4}$ as a single phase without the existence of any second phase. Using the glycine-assisted combustion process, however, the relative intensities of diffraction peaks indexed to $\mathrm{NiMn}_{2} \mathrm{O}_{4}$ increase. 


\subsection{Fourier-Transform Infrared (FTIR) Investigation}

The study of both the position and vibration modes of the ions in the crystal structure of the compounds can be determined by FTIR analysis. In other words, the FTIR technique enabled us to study the different ordering positions of ions on the structural characteristics of materials. However, FTIR spectroscopy is an important tool to identify the functional groups, phase and purity of samples. The FTIR spectral study of the as synthesized nickelmanganese mixed oxides were recorded between 4000 and $400 \mathrm{~cm}^{-1}$ as shown in Figure 3 . It is known that the specified bands of inorganic solids in the region of 1000 and $400 \mathrm{~cm}^{-1}$ are usually determined to the vibration of metallic ions in the crystal lattice [25].
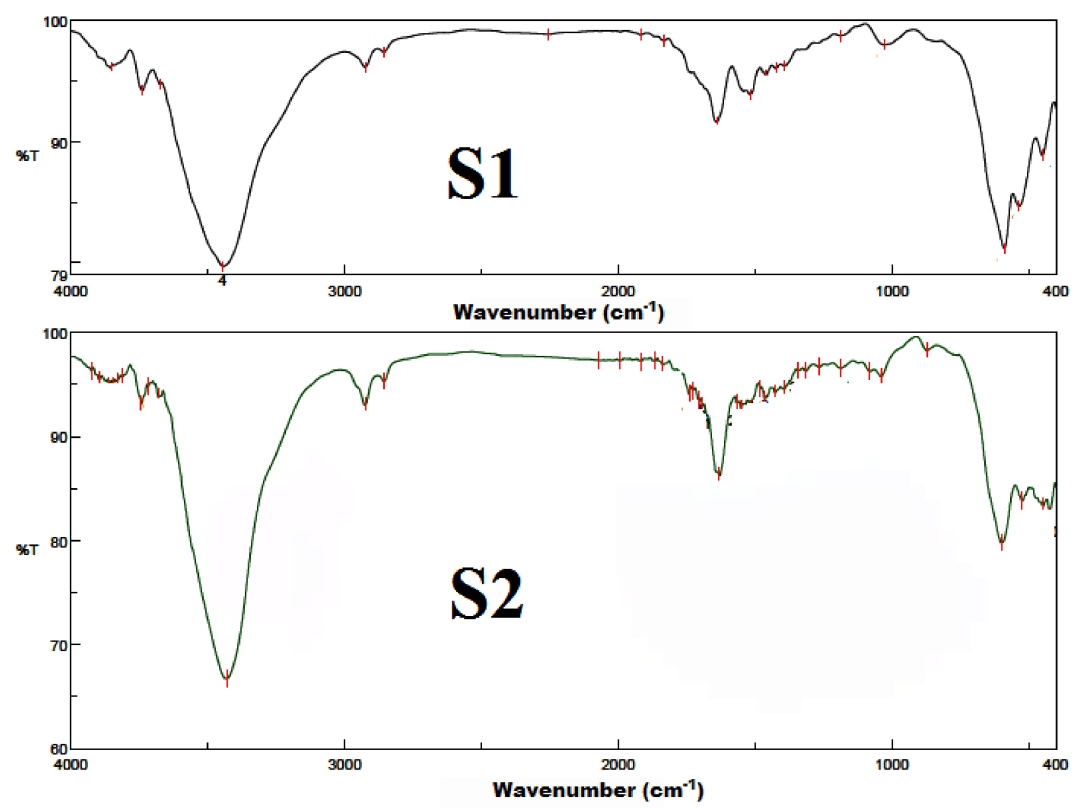

Figure 3. FT-IR patterns of the S1 and S2 samples.

Based on the group theoretical calculations, the manganite-based materials are known to exhibit two fundamentals IR active modes in the vibration spectra, which were observed around $600 \mathrm{~cm}^{-1}$ for tetrahedral (A) site and around $400 \mathrm{~cm}^{-1}$ for octahedral (B) site [26]. In this study, the absorption bands for spinel nickel manganites are in the expected range. The as synthesized manganites show strong absorption bands at $599-589 \mathrm{~cm}^{-1}$ and $535-525 \mathrm{~cm}^{-1}$. Indeed, the bands, $\gamma_{1}$, at $599-589 \mathrm{~cm}^{-1}$ and the bands, $\gamma_{2}$, at $535-525 \mathrm{~cm}^{-1}$ are a result of the $\mathrm{A}^{-}$and $\mathrm{B}^{-}$complexes of spinel manganite type structure, respectively. $\mathrm{A}$ broad and week bands, $\gamma_{2}{ }^{*}$, located at $450-425 \mathrm{~cm}^{-1}$ is assigned to the divalent octahedral metal ion and oxygen ion complexes. In other words, the octahedral bands exhibit splitting of absorption bands including few small subsidiary bands. Detected subsidiary bands are mainly due to John-Teller distortion evolved by the presence of $\mathrm{Mn}^{2+}$ ions [27]. Moreover, the absorption bands located at $3445-3430 \mathrm{~cm}^{-1}$ and $1639-1630 \mathrm{~cm}^{-1}$ were a result of the stretching and bending mode of the $\mathrm{OH}$ group of absorbed water molecules on the $\mathrm{Ni}-\mathrm{Mn}-\mathrm{O}$ lattice since the nano crystalline materials have a high surface-volume ratio and thus absorb moisture [28-30]. However, using of glycine-based combustion method resulted in slightly change in the positions and intensities of detected bands due to the surface and quantum size effects of nanomaterials [31].

\subsection{HRTEM and EDX Analyses}

In this study, we found that both the presence of glycine and the magnetic nature of the resultant materials had a clear effect on the morphological characteristics of the as prepared samples. High-resolution TEM (HRTEM) images of the S1 and S2 are clear Figures $4 \mathrm{a}$ and $5 \mathrm{a}$ and also the distinct fringes are depicted in Figures $4 \mathrm{~b}$ and $5 \mathrm{~b}$. On the other hand, the data of these fringes were analyzed with the software of Digital Micrograph 
using the fast Fourier transform (FFT) as shown in, Fourier mask filtering tools and inverse Fourier transform (IFFT) are described as inserts on the left and the right of Figures $4 \mathrm{~b}$ and $5 \mathrm{~b}$.

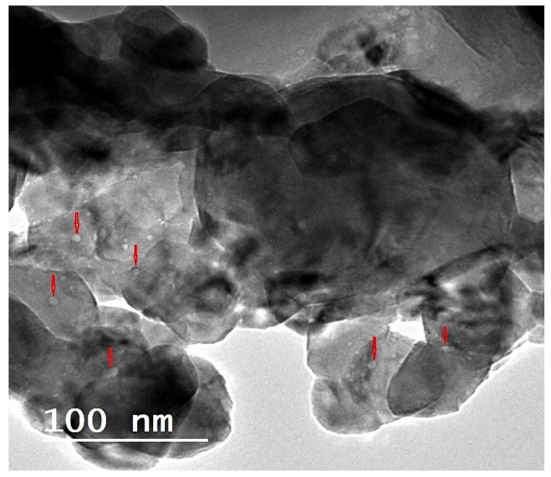

(a)

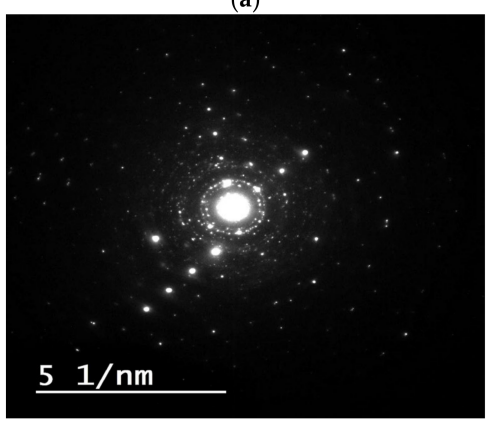

(c)

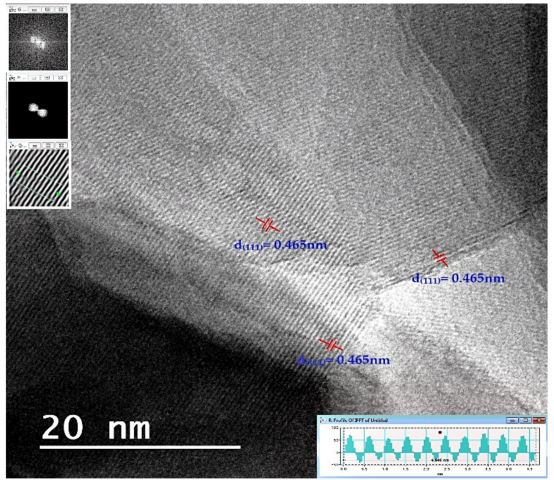

(b)

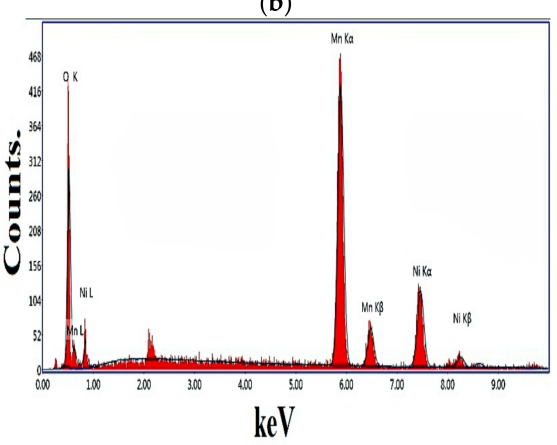

(d)

Figure 4. ((a): HRTEM, (b): FFT, (c): SAED and (d): EDX) images of the S1.

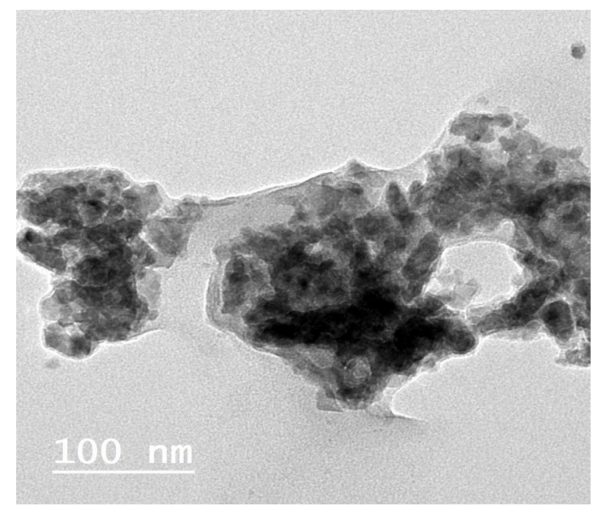

(a)

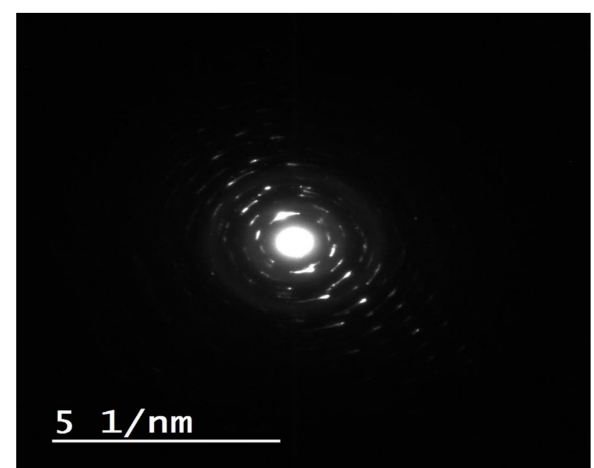

(c)

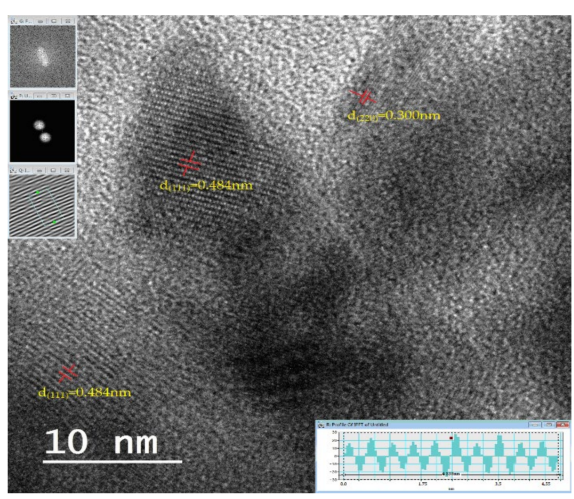

(b)

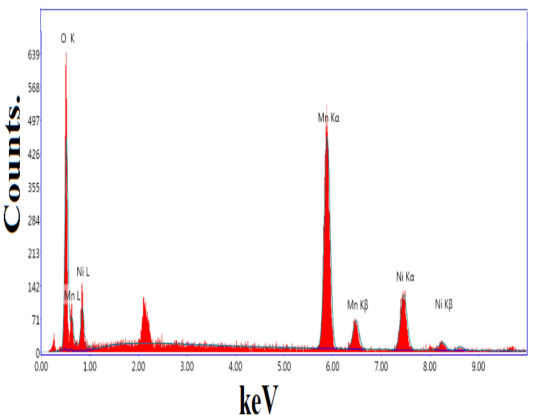

(d)

Figure 5. ((a): HRTEM, (b): FFT, (c): SAED and (d): EDX) images of the S2 samples. 
As shown in Figure 5a, uniformly dispersed porous and polyhedron-structured particles with an average diameter of about $22 \mathrm{~nm}$ were successfully synthesized by glycineassisted combustion method. On the other side, the ceramic method resulted in formation numerous small sizes of particles (referred by red arrows) on the uppermost layers for the relatively large size type particles (average size $\approx 55 \mathrm{~nm}$ ) accumulated with porous structure as noted in Figure 4a.

This observation confirms the XRD results of the S1 sample which consisted of $\mathrm{NiMn}_{2} \mathrm{O}_{4}$ (major phase) besides both $\mathrm{Mn}_{2} \mathrm{O}_{3}$ and $\mathrm{NiMnO}_{3}$ phases. One cannot ignore the action of the magnetic nature of the as prepared nano particles, which led to slightly agglomerations. The difference in the shape, size and aggregation of the grains of the prepared materials was clearly observed in the TEM images. This is probably because of the different fabrication mechanisms depending upon the difference in the energy during the glycine combustion. In the case of S2 sample, escaping large amounts of gases during the process of auto-combustion for the used precursors brought about appearance of various porous and voids yielding very fine particles. The lattice spaces of $0.484 \mathrm{~nm}$ or $0.465 \mathrm{~nm}$ and $0.300 \mathrm{~nm}$ for $\mathrm{NiMn}_{2} \mathrm{O}_{4}$ are in good agreement with the inter-plane space of the spinel-type $\mathrm{NiMn}_{2} \mathrm{O}_{4}(111)$ and (220) planes (PDF 01-1110), respectively. Figures $4 \mathrm{c}$ and $5 \mathrm{c}$ display the selected area electron diffraction (SAED) patterns of the prepared samples. The SAED patterns are made up of a series of light diffraction circles with a variety of spots that reflect the presence of porous materials with a polycrystalline structure. These observations are consistent with the TG and XRD results and also confirm the solid-solid interaction between the constituents of the as prepared solids and/or phase transformation.

Identification of the elements present in the as prepared solid can be occurred by using EDX analysis. However, this technique can provide us the concentrations of the elements on the solid surface. In addition, the redistribution of the elements at top layers of the solid surface can be detected by carrying out the analysis at different points or various areas at the solid surface. Figures $4 \mathrm{~d}$ and 5d display representative EDX analyses for the S1 and S2 samples prepared by ceramic and glycine-assisted combustion methods, respectively. From the EDX results, the presence of $\mathrm{Ni}, \mathrm{Mn}$ and $\mathrm{O}$ elements in different samples were confirmed. However, the relative atomic abundance of $\mathrm{Ni}, \mathrm{Mn}$ and $\mathrm{O}$ elements at three different areas are much closer to each other of the prepared solids as determined in Table 1. The close values of each element in different regions indicate the homogeneity of the distribution of this element in the prepared sample. This was observed for all elements in different samples. Moreover, the glycine based green synthesis of nickel manganite brought about synthesis of homogeneously distributed particles.

Table 1. Atomic abundance of elements measured at $20 \mathrm{keV}$ and different areas over the as prepared solids.

\begin{tabular}{ccccc}
\hline Solids & Elements & Area 1 & Area 2 & Area 3 \\
\hline S1 & O & 42.61 & 53.76 & 50.31 \\
& Mn & 38.08 & 31.33 & 32.34 \\
& Ni & 17.92 & 14.23 & 16.44 \\
& O & 50.31 & 51.25 & 54.94 \\
& Mn & 33.34 & 32.15 & 29.24 \\
S2 & Ni & 15.44 & 16.60 & 15.81 \\
\hline
\end{tabular}

\subsection{Magnetic Characteristics}

The magnetization of the synthesized solids was measured as a function of applied magnetic field in the range of $-20,000$ to $+20,000 \mathrm{G}$ using VSM at room temperature. Figure 6 shows the magnetization curves of the as prepared samples. 

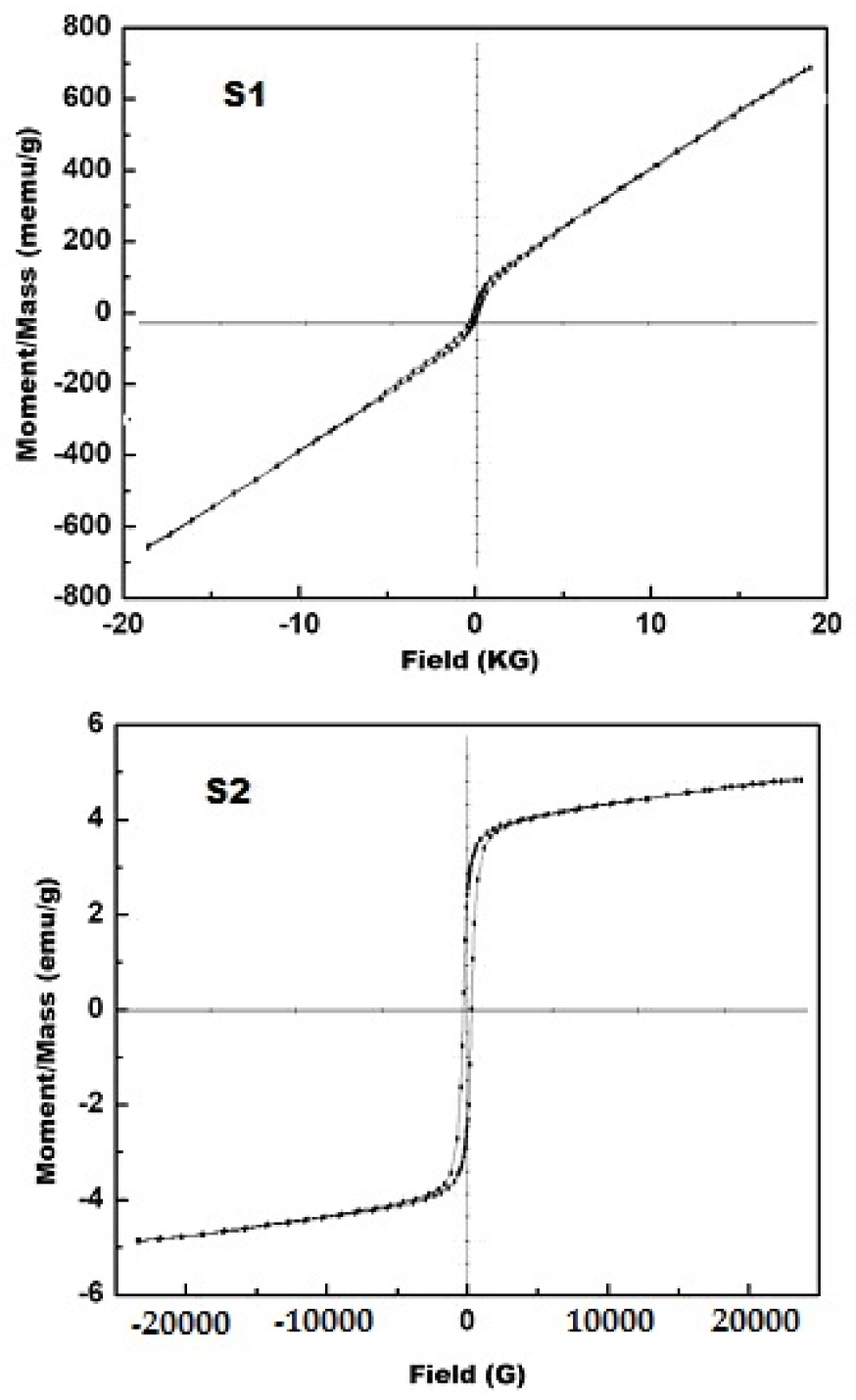

Figure 6. M-H curve of the S1 and S2 samples.

However, the values of coercive field $\left(\mathrm{H}_{\mathrm{c}}\right)$, remanent magnetization $\left(\mathrm{M}_{\mathrm{r}}\right)$, saturation magnetization $\left(\mathrm{M}_{\mathrm{s}}\right)$, squareness $\left(\mathrm{M}_{\mathrm{r}} / \mathrm{M}_{\mathrm{s}}\right)$, anisotropy constant $\left(\mathrm{K}_{\mathrm{a}}\right)$ and magnetic moment $\left(\mu_{\mathrm{m}}\right)$ per unit formula in Bohr magnetron of the synthesized specimens are listed in Table 2. This table showed that the values of $\mathrm{H}_{\mathrm{c}}, \mathrm{M}_{\mathrm{r}}, \mathrm{M}_{\mathrm{s}}, \mathrm{M}_{\mathrm{r}} / \mathrm{M}_{\mathrm{s}}, \mu_{\mathrm{m}}$ and $\mathrm{K}_{\mathrm{a}}$ for the $\mathrm{S} 2$ sample are greater than that of S1 sample.

Table 2. Magnetic properties $\left(\mathrm{M}_{\mathrm{s}}, \mathrm{M}_{\mathrm{r}}, \mathrm{M}_{\mathrm{r}} / \mathrm{M}_{\mathrm{s}}, \mathrm{K}_{\mathrm{a}}, \mu_{\mathrm{m}}\right.$ and $\left.\mathrm{H}_{\mathrm{c}}\right)$ of the as-prepared solids.

\begin{tabular}{ccccccc}
\hline Solids & $\mathbf{M}_{\mathbf{s}}(\mathbf{e m u} / \mathbf{g})$ & $\mathbf{M}_{\mathbf{r}}(\mathbf{e m u} / \mathbf{g})$ & $\mathbf{M}_{\mathbf{r}} / \mathbf{M}_{\mathbf{s}}(\mathbf{e m u} / \mathbf{g})$ & $\mathbf{H}_{\mathbf{c}}(\mathbf{O e})$ & $\boldsymbol{\mu}_{\mathbf{m}}$ & Anisotropy Constant $\left(\mathbf{K}_{\mathbf{a}}\right)$ \\
\hline S1 & 0.6824 & $19.26 \times 10^{-3}$ & $28.24 \times 10^{-3}$ & 146.74 & 102.179 & $2.864 \times 10^{-2}$ \\
\hline S2 & 5.0216 & 2.5034 & 0.4985 & 229.5 & 1152.457 & $21.074 \times 10^{-2}$ \\
\hline
\end{tabular}

\section{Discussion}

\subsection{Formation of Perouskite-Spinel Nickel Manganites}

Polycrystalline samples containing $\mathrm{Mn}_{2} \mathrm{O}_{3} / \mathrm{NiMnO}_{3} / \mathrm{NiMn}_{2} \mathrm{O}_{4}$ and $\mathrm{NiMn}_{2} \mathrm{O}_{4}$ have been synthesized using both the ceramic route and the combustion synthetic route using glycine as fuel followed by heating at elevated temperatures, respectively. Generally, $\mathrm{Ni}_{x} \mathrm{Mn}_{3-\mathrm{x}} \mathrm{O}_{4}$ materials crystallize in air to produce a cubic spinel $\mathrm{NiMn}_{2} \mathrm{O}_{4}$ solid at 
$730-875{ }^{\circ} \mathrm{C}$. Below and above this temperature range, mixture of $\mathrm{NiMnO}_{3}$ and $\mathrm{Mn}_{2} \mathrm{O}_{3}$ were permanent phases depending on single-phase of $\mathrm{NiMn}_{2} \mathrm{O}_{4}$ cannot be formed [32]. However, in our previous work, we reported to formation of $\mathrm{NiMn}_{2} \mathrm{O}_{4}$ as a single phase [21]. This was achieved by heating at $950{ }^{\circ} \mathrm{C}$ for the mixture of precursors containing equimolar ratio of nickel and manganese nitrates with and without a certain amount of egg white [21]. In other words, these findings were opposite the results which obtained by Wickham [32]. This difference was extended in this study, when the mixture of $\mathrm{Mn}_{2} \mathrm{O}_{3}$ and perovskite $\mathrm{NiMnO}_{3}$, in addition, spinel $\mathrm{NiMn}_{2} \mathrm{O}_{4}$ were obtained from heating equimolar ratio of Ni$\mathrm{Mn}$ nitrates at $700{ }^{\circ} \mathrm{C}$ for $2 \mathrm{~h}$. Moreover, we were able to inhibit formation of both $\mathrm{Mn}_{2} \mathrm{O}_{3}$ and $\mathrm{NiMnO}_{3}$ at $700{ }^{\circ} \mathrm{C}$ and their transformation completely into single phase of $\mathrm{NiMn}_{2} \mathrm{O}_{4}$ by using of glycine. XRD results confirmed formation of $\mathrm{NiMn}_{2} \mathrm{O}_{4}(48 \%), \mathrm{NiMnO}_{3}(41 \%)$ as major phases and $\mathrm{Mn}_{2} \mathrm{O}_{3}(12 \%)$ as a minor phase at $700{ }^{\circ} \mathrm{C}$ with crystallite size of $22 \mathrm{~nm}$, $38 \mathrm{~nm}$ and $27 \mathrm{~nm}$, respectively. In other words, the heat treatment at $700{ }^{\circ} \mathrm{C}$ is insufficient for complete conversion of $\mathrm{Ni}$ and $\mathrm{Mn}$ oxides to $\mathrm{NiMn}_{2} \mathrm{O}_{4}$ solid as single phase depending on the following equation:

$$
2 \mathrm{NiMnO}_{3}+1.5 \mathrm{Mn}_{2} \mathrm{O}_{3} \rightarrow \mathrm{NiMn}_{2} \mathrm{O}_{4}+\mathrm{NiMnO}_{3}+\mathrm{Mn}_{2} \mathrm{O}_{3}+0.5 \mathrm{O}_{2}
$$

\subsection{Formation of Spinel Nickel Manganite}

The previous findings necessitated adding a certain amount of glycine followed by heating of the materials at $700{ }^{\circ} \mathrm{C}$, which led to the acquisition of $\mathrm{NiMn}_{2} \mathrm{O}_{4}$ as a single phase. At the starting point, the solid-state reaction between manganese and nickel oxides brought about thin film of manganite which covers the grains surfaces of reacting oxides and acts as energy barrier of manganite formation. However, the glycine treatment followed by heating at $700{ }^{\circ} \mathrm{C}$ enhanced the thermal diffusion of the reacting oxides through the previous thin film of $\mathrm{NiMn}_{2} \mathrm{O}_{4}$ with subsequent complete conversion of $\mathrm{NiMnO}_{3}$ and $\mathrm{Mn}_{2} \mathrm{O}_{3}$ yielding single phase of $\mathrm{NiMn}_{2} \mathrm{O}_{4}$. Indeed, the results of XRD for the S2 sample showed disappearance of all peaks related to $\mathrm{NiMnO}_{3}$ and $\mathrm{Mn}_{2} \mathrm{O}_{3}$ with subsequent presence of sharp peaks related to crystalline of $\mathrm{NiMn}_{2} \mathrm{O}_{4}$. Finally, the nickel manganite studied experienced a transformation from perovskite to spinel phase and also cation redistribution by using a glycine-based combustion method at $700{ }^{\circ} \mathrm{C}$.

\subsection{Cation Distribution of Spinel Nickel Manganite}

Spinel nickel manganite $\left(\mathrm{NiMn}_{2} \mathrm{O}_{4}\right)$ has different physical and chemical behaviors depending on the type and amount of cations occupying $\mathrm{A}^{-}$and $\mathrm{B}^{-}$sites [33]. In other words, the variability of the $\mathrm{Ni}$ and $\mathrm{Mn}$ lattice positions resulted in the interesting structural and magnetic characteristics of spinel $\mathrm{NiMn}_{2} \mathrm{O}_{4}$ yielding different applications. As reported earlier $\mathrm{Mn}^{2+}$ ions have a strong preference to occupy A sites while $\mathrm{Ni}^{2+}$ and $\mathrm{Mn}^{3+}$ have preferentially occupied the B site $[21,33,34]$. According to one study, $\mathrm{Ni}^{2+}$ can be found in the $\mathrm{A}^{-}$site depending on various factors such as calcination temperature and preparation route [34]. Ni and Mn cations can also occupy tetrahedral and octahedral crystal sites, which are interstitial sites within the cubic closed packed oxygen sub-lattice of the spinel structure, according to literature. Cation distribution mechanism of $\mathrm{NiMn}_{2} \mathrm{O}_{4}$ spinel may be explained in light of the migration of cations between $\mathrm{B}^{-}$and $\mathrm{A}^{-}$sites followed by a change in their valences in order to suppress the Jahn Teller distortion. This distortion resulted in lattice instability of solid due to the departure from ideal interactions among bonding orbital [35]. Indeed, this distortion can be examined from the XRD pattern of the S1 and S2 samples depending upon the study of the peaks observed at (2 20 ) and (4 40 ) reflection planes. The intensities of these planes are more sensitive to the cations on tetrahedral and octahedral sites, respectively [36]. It can be observed from Table 3 that the ratio of $\mathrm{I}_{220} / \mathrm{I}_{440}$ changes with and without glycine indicating to the cation redistribution.

Some authors speculated that a portion of the $\mathrm{Ni}^{2+}$ cations can be moved from $\mathrm{A}^{-}$to $\mathrm{B}^{-}$sites, then a corresponding proportion of $\mathrm{Mn}^{3+}$ cations in $\mathrm{B}^{-}$sites disproportionate to $\mathrm{Mn}^{2+}$ and $\mathrm{Mn}^{4+}$ [37-39]. However, the $\mathrm{Mn}^{2+}$ cations move to A- sites to compensate for the $\mathrm{Ni}^{2+}$ vacancies. In this study, the maximum increase in the intensity of (2 20$)$ and (4 40$)$ 
planes, due to the glycine treatment followed by heating at $700{ }^{\circ} \mathrm{C}$, attained $61 \%$ and $20 \%$, respectively. This proves that the presence of cations at $\mathrm{A}^{-}$site is greater than that at $\mathrm{B}^{-}$ site. Based on IR measurements, the intensity of peak band related to $\mathrm{A}^{-}$site for the S2 sample is greater than that for the $\mathrm{S} 1$ sample depending upon $\mathrm{NiMn}_{2} \mathrm{O}_{4}$ has various states of manganese ions $\left(\mathrm{Mn}^{2+}, \mathrm{Mn}^{3+}\right.$ and $\left.\mathrm{Mn}^{4+}\right)$ that distributed between $\mathrm{A}^{-}$and $\mathrm{B}^{-}$sites.

Table 3. Lattice parameters of nanocrystalline $\mathrm{NiMn}_{2} \mathrm{O}_{4}$ involved in the as prepared solids.

\begin{tabular}{cccc}
\hline Parameters & Solids & S1 & S2 \\
\hline & Crystal Structure & Cubic Spinel & Cubic Spinel \\
\hline $\mathrm{d}, \mathrm{nm}$ & 55 & 22 \\
\hline $\mathrm{a}, \mathrm{nm}$ & 0.8416 & 0.8387 \\
\hline $\mathrm{V}, \mathrm{nm}^{3}$ & 0.5961 & 0.5899 \\
\hline $\mathrm{D}_{\mathrm{x}, \mathrm{g} / \mathrm{cm}^{3}}$ & 5.222 & 5.276 \\
\hline $\mathrm{L}_{\mathrm{A}}, \mathrm{nm}$ & 0.3644 & 0.3632 \\
\hline $\mathrm{L}_{\mathrm{B}}, \mathrm{nm}$ & 0.2971 & 0.2961 \\
\hline $\mathrm{A}-\mathrm{O}, \mathrm{nm}$ & 0.1924 & 0.1917 \\
\hline $\mathrm{B}_{-} \mathrm{O}, \mathrm{nm}$ & 0.2171 & 0.2160 \\
\hline $\mathrm{r}_{\mathrm{A}}, \mathrm{nm}$ & 0.0604 & 0.0597 \\
\hline $\mathrm{r}_{\mathrm{B}}, \mathrm{nm}$ & 0.0851 & 0.0844 \\
\hline $\mathrm{I}_{220} / \mathrm{I}_{440}$ & 0.96 & 1.29 \\
\hline
\end{tabular}

d-crystallite size, a-lattice constant of cubic cell, $\mathrm{V}-$ volume of unit cell, $\mathrm{D}_{\mathrm{x}}-\mathrm{X}$-ray density, $\mathrm{L}_{\mathrm{A}}$ and $\mathrm{L}_{\mathrm{B}}-$ distances between the reacting ions, $\mathrm{A}-\mathrm{O}$ and $\mathrm{B}-\mathrm{O}-$ Bond length, $\mathrm{r}_{\mathrm{A}}$ and $\mathrm{r}_{\mathrm{B}}$-ionic radii, $\mathrm{I}_{220} / \mathrm{I}_{440}$ - Intensity ratio of two planes.

Thus, the authors confirm that the glycine treatment followed by heating at $700{ }^{\circ} \mathrm{C}$ of Ni-Mn mixed oxides brought about changes in related structural properties namely, the crystallite size $(d)$, lattice constant $(a), X$-ray density $\left(D_{x}\right)$, distance between the reacting ions $\left(\mathrm{L}_{\mathrm{A}}\right.$ and $\left.\mathrm{L}_{\mathrm{B}}\right)$, ionic radii $\left(\mathrm{r}_{\mathrm{A}}, \mathrm{r}_{\mathrm{B}}\right)$ and bond lengths $(\mathrm{A}-\mathrm{O}$ and $\mathrm{B}-\mathrm{O})$ on tetrahedral $(\mathrm{A})$ sites and octahedral (B) sites of $\mathrm{NiMn}_{2} \mathrm{O}_{4}$ spinel as shown in Table 3 [40-42]. These findings could be attributed to the enhancement effect of glycine in formation nanosized particles depending upon redistribution of reacting cations and liberation of different gases during the preparation process.

Nickel manganite in the cubic spinel structure exhibits some oxygen vacancies or defects with release oxygen at the temperatures elevated. The vacancy formation was explained by the defect equation in Kroger-Vink notations as follows [43,44]:

$$
\mathrm{O}_{\mathrm{o}}{ }^{\mathrm{x}} \leftrightarrow \mathrm{V}_{\mathrm{o}}^{\bullet \bullet}+2 \mathrm{e}^{-}+0.5 \mathrm{O}_{2}
$$

where $\mathrm{O}_{\mathrm{o}}{ }^{\mathrm{x}}$ is the oxide ion in the lattice, $\mathrm{V}_{\mathrm{o}}{ }^{\bullet \bullet}$ is doubly charged oxygen vacancy, $\mathrm{e}^{-}$ is the electron in the conduction band. This finding brought about conversion of some $\mathrm{Mn}^{3+}$ to $\mathrm{Mn}^{4+}$ ions. However, the electrons formed during the previous reduction convert equivalent amount of $\mathrm{Mn}^{3+}$ to $\mathrm{Mn}^{2+}$ ions and lead to a distortion of the local symmetry in the crystals. These changes resulted in change in the bond length (A-O and B-O) and overall lattice parameters [45]. However, these parameters decrease as the size of the particles decreases as shown in case of the $\mathrm{S} 2$ sample.

\subsection{Magnetic Properties}

In fact, it has been referred that $\mathrm{NiMn}_{2} \mathrm{O}_{4}$ is not a simple ferromagnet because it contains both ferromagnetic and antiferromagnetic sublattices [14,31,46-48]. In addition, the exchange between $\mathrm{Ni}^{2+}$ and $\mathrm{Mn}^{3+}$ has antiferromagnetic character while the exchange between $\mathrm{Mn}^{2+}$ and $\mathrm{Mn}^{3+}$ has ferromagnetic behavior. This magnetic behavior is caused by strong coupling between A-B sites [49]. In this research, the glycine-based combustion route 
led to enhancement in the ferromagnetism of the manganite studied. This increase could be due to the transformation of $\mathrm{Mn}_{2} \mathrm{O}_{3} / \mathrm{NiMnO}_{3}$ to $\mathrm{NiMn}_{2} \mathrm{O}_{4}$ with subsequent decrease in the crystallite size, hole density, and the Zener double exchange (ZDE) mechanism of $\mathrm{NiMn}_{2} \mathrm{O}_{4}$ spinel [31,47,48]. Indeed, the glycine-based combustion route compared to the ceramic method led to a decrease in the crystallite size of $\mathrm{NiMn}_{2} \mathrm{O}_{4}$ spinel from $55 \mathrm{~nm}$ to $22 \mathrm{~nm}$, respectively. However, the preparation of solid by glycine-assisted combustion route brought about appearance of ZDE mechanism leading to enhanced hole density. This is achieved by migration of some $\mathrm{Ni}^{2+}$ ions from $\mathrm{B}$ site to $\mathrm{A}$ site with subsequent conversion of some $\mathrm{Mn}^{3+}$ ions to both $\mathrm{Mn}^{2+}$ ions and $\mathrm{Mn}^{4+}$ ions which is adopted to $\mathrm{B}^{-}$site while the $\mathrm{Mn}^{2+}$ ion will be adopted to tetrahedral site [50]. On the other hand, the super exchange interaction between $\mathrm{Mn}^{3+}-\mathrm{O}^{2-}-\mathrm{Ni}^{2+}$ (A-B interaction) became weak due to reduction of some $\mathrm{Mn}^{3+}$ ions.

In addition, the changes in the bond lengths between the cation-cation (M-M) and cation-anion (M-O) alter the overall strength of the magnetic interactions (A-A, B-B and $A-B)$ in $A$ and $B$ sublattices. The strength of the magnetic interaction is inversely related to the bond length. Table 3 displays that the values of $\mathrm{L}_{\mathrm{A}}, \mathrm{L}_{\mathrm{B}}, \mathrm{A}-\mathrm{O}$ and $\mathrm{B}-\mathrm{O}$ for the $\mathrm{S} 2$ sample are smaller than that of the S1 sample. $\mathrm{M}_{\mathrm{r}} / \mathrm{M}_{\mathrm{S}}$ values are found to be around 0.5 for the S2 sample which is the expected value for randomly packed single domain particles [49]. Coercivity of a manganite system is known to depend on various parameters, like magnetocrystalline anisotropy, lattice imperfections, grain size and shape, porosity and secondary phases. The low-coercive component may be due to other phases apparent in the XRD pattern ordering of the maganite nanoparticles affecting the nanoparticles ${ }^{\prime}$ anisotropy. Preparation of $\mathrm{NiMn}_{2} \mathrm{O}_{4}$ spinel using glycine-assisted combustion method resulted in an increase in the anisotropy constant with subsequent decrease in the value of $\mathrm{r}_{\mathrm{A}}$ and $\mathrm{r}_{\mathrm{B}}$ yielding large coercivity.

\section{Conclusions}

The ceramic technique and also the combustion method based on glycine, followed by heating at $700{ }^{\circ} \mathrm{C}$ for $2 \mathrm{~h}$, were used to form both $\mathrm{Mn}_{2} \mathrm{O}_{3} / \mathrm{NiMnO}_{3} / \mathrm{NiMn}_{2} \mathrm{O}_{4}$ nanocomposite and $\mathrm{NiMn}_{2} \mathrm{O}_{4}$ nanoparticles, respectively. The combustion method has a number of advantages, including cost effectiveness, scalability and faster synthesis of $\mathrm{NiMn}_{2} \mathrm{O}_{4}$ nanoparticles with a cubic spinel structure. Indeed, this method resulted in phase transformation of manganite from perovskite structure to spinel structure. An important observation of the work is formation of $\mathrm{NiMn}_{2} \mathrm{O}_{4}$ as prominent phase formation with complete suppression of $\mathrm{NiMnO}_{3}$ and $\mathrm{Mn}_{2} \mathrm{O}_{3}$ phases. The suppression of these oxides is attributed to complete conversion of these oxides to $\mathrm{NiMn}_{2} \mathrm{O}_{4}$ phase via the solid-state reaction. The combustion method led to modification of cation distribution in $\mathrm{NiMn}_{2} \mathrm{O}_{4}$ spinel yielding enhanced ferromagnetism. The elemental and morphological investigations of the prepared samples carried out using EDX and HRTEM techniques, respectively. The as-prepared $\mathrm{NiMn}_{2} \mathrm{O}_{4} \mathrm{NPs}$ by using the combustion method had coercivity (229.50 Oe) and saturation magnetization $(5.0216 \mathrm{emu} / \mathrm{g})$. Finally, the glycine-assisted combustion method led to formation of manganites having best properties compared to the ceramic method at the same of preparation temperature.

Author Contributions: N.M.D., G.M.A.-S., N.S.A.-K. as well as O.H.A.-E.; technique, N.M.D., G.M.A.-S., N.S.A.-K. and O.H.A.-E.; program, O.H.A.-E.; validation N.M.D., G.M.A.-S., N.S.A.K. and O.H.A.-E.; formal analysis, N.M.D., G.M.A.-S. and O.H.A.-E.; systematic evaluation, N.M.D., G.M.A.-S. and O.H.A.-E.; inquiry, N.M.D., G.M.A.-S.; resources, N.M.D., G.M.A.-S. and O.H.A.-E.; curation of results, N.M.D., G.M.A.-S. and O.H.A.-E.; writing-original preparation of the draft, N.M.D. and O.H.A.-E.; writing-review and editing, N.M.D., G.M.A.-S. and O.H.A.-E.; visualization, N.M.D. and O.H.A.-E.; supervision, N.M.D. and O.H.A.-E.; project management, N.M.D., G.M.A.-S. and O.H.A.-E.; procurement of financing, G.M.A.-S. and N.S.A.-K. All authors have read and agreed to the published version of the manuscript.

Funding: This research was funded by the Deanship of Scientific Research at Princess Nourah bint Abdulrahman University through the fast-track research-funding program. 
Institutional Review Board Statement: Not applicable.

Informed Consent Statement: Not applicable.

Data Availability Statement: The data presented in this study are available on request from the corresponding author.

Acknowledgments: The authors would like to extend their sincere appreciation to Deanship of Scientific Research at Princess Nourah bint Abdulrahman University through the fast-track researchfunding program.

Conflicts of Interest: The authors declare no conflict of interest.

\section{References}

1. Deraz, N.M.; El-Aiashy, M.K.; Ali, S.A. Novel Preparation and Physicochemical Characterization of a Nanocrystalline Cobalt Ferrite System. Adsorp. Sci. Technol. 2009, 27, 797-810. [CrossRef]

2. Deraz, N.M. Tailoring the Physicochemical and Magnetic Properties of an Mn Substituted Cobalt Ferrite System. Interceram 2018, 67, 14-19. [CrossRef]

3. Shao, L.; Wang, P.X.; Zhang, N.Q.; Fan, L.; Zhang, N.; Sun, K.N. Nanostructured $\mathrm{CuCo}_{2} \mathrm{O}_{4}$ cathode for intermediate temperature solid oxide fuel cells via an impregnation technique. J. Power Sour. 2017, 343, 268-274. [CrossRef]

4. Lu, B.; Cao, D.; Wang, P.; Gao, Y. Oxygen evolution reaction on Ni-substituted $\mathrm{Co}_{3} \mathrm{O}_{4}$ nanowire array electrodes. Int. J. Hydrogen Energy 2011, 36, 72-78. [CrossRef]

5. Jung, J.; Töpfer, J.; Mürbe, J.; Feltz, A. Microstructure and phase development in $\mathrm{NiMn}_{2} \mathrm{O}_{4}$ spinel ceramics during isothermal sintering. J. Eur. Ceram. Soc. 1990, 6, 351-359. [CrossRef]

6. Schmidt, R.; Basu, A.; Brinkman, A.W. Small polaron hopping in spinel manganates. Phys. Rev. B 2005, 72, 115101-115109. [CrossRef]

7. Chengjian, M.; Hong, G. Preparation and characterization of single-phase $\mathrm{NiMn}_{2} \mathrm{O}_{4}$ NTC ceramics by two-step sintering method. J. Mater. Sci. Mater. Electron. 2017, 28, 6699-6703.

8. Tsuda, N.; Nasu, K.; Fujimori, A.; Siratori, K. Electronic Conduction in Oxides, 2nd ed.; Springer Series in Solid-State Sciences; Springer: Berlin, Germany, 2000.

9. Shuling, L.; Jin, X.; Zhong, M.; Shiming, Z.; Xiufang, W.; Xuebin, Y.; Yang, J.; Zi-Feng, M.; Xianxia, T. NiMn ${ }_{2} \mathrm{O}_{4}$ as an efficient cathode catalyst for rechargeable lithium-air batteries. Chem. Commun. 2017, 53, 8164-8167.

10. Brabers, V.A.M.; Terhell, J.C.J.M. Electrical conductivity and cation valencies in nickel manganite. Phys. Status Solidi 1982, 69, 325-331. [CrossRef]

11. Zener, C. Interaction between the d shells in the transition metals. Phys. Rev. 1951, 81, 440-444. [CrossRef]

12. Feteira, A. Negative temperature coefficient resistance (NTCR) ceramic thermistors: An industrial perspective. J. Am. Ceram. Soc. 2009, 92, 967-983. [CrossRef]

13. Hosseini, S.A.; Niaei, A.; Salari, D.; Nabavi, S.R. Nanocrystalline $\mathrm{AMn}_{2} \mathrm{O}_{4}(\mathrm{~A}=\mathrm{Co}, \mathrm{Ni}, \mathrm{Cu})$ spinels for remediation of volatile organic compounds-Synthesis, characterization and catalytic performance. Ceram. Int. 2012, 38, 1655-1661. [CrossRef]

14. Cheeseman, N.B.B.; Chopdekar, R.V.; Iwata, J.M.; Toney, M.F.; Arenholz, E.; Suzuki, Y. Modified magnetic ground state in $\mathrm{NiMn}_{2} \mathrm{O}_{4}$ thin films. Phys. Rev. B 2010, 82, 144419. [CrossRef]

15. Takayama, S.; Fukushima, J.; Nishijo, J.; Saito, M.; Sano, S.; Sato, M. Sintering of soft magnetic material under microwave magnetic field. Phys. Res. Int. 2014, 2102, 165849. [CrossRef]

16. Nan, H.; Ma, W.; Gu, Z.; Geng, B.; Zhang, X. Hierarchical NiMn $\mathrm{O}_{4} @ \mathrm{CNT}$ nanocomposites for high-performance asymmetric supercapacitors. RSC Adv. 2015, 5, 24607-24614. [CrossRef]

17. Selim, M.M.; Deraz, N.M.; El-Asmy, A.A.; El-Shafey, O. Synthesis, characterization and physicochemical properties of nanosized Zn/Mn oxides system. J. Alloy. Compd. 2010, 506, 541-547. [CrossRef]

18. Schmidt, R.; Brinkman, A.W. Preparation and characterization of $\mathrm{NiMn}_{2} \mathrm{O}_{4}$ films. Int. J. Inorg. Mater. 2001, 3, $1215-1217$. [CrossRef]

19. Pena, O.; Moure, C.; Bodenez, V.; Caileaux, X.; Piriou, B.; Ortiz, J.; Zuniga, G.; Gautier, J.L.; Fliho, J.L.G. Magnetic properties of spinel-type oxides $\mathrm{NiMn}_{2-\mathrm{x}} \mathrm{M}_{\mathrm{ex}} \mathrm{O}_{4}$. J. Chil. Chem. Soc. 2005, 50, 617-623. [CrossRef]

20. Durán, P.; Tartaj, J.; Rubio, F.; Peña, O.; Moure, C. Preparation and sintering behaviour of spinel-type $\mathrm{Co}_{x} \mathrm{NiMn}_{2-\mathrm{x}} \mathrm{O}_{4}(0.2 \leq \mathrm{x} \leq 1.2)$ by the ethylene glycol-metal nitrate polymerized complex process. J. Eur. Ceram. Soc. 2005, 15, 3021-3025. [CrossRef]

21. Deraz, N.M.; Abd-Elkader, O.H.; Yassin, M. Impacts of egg white assisted combustion and ceramic methods on structural, morphological and magnetic properties of Nickel Manganite system. Crystals 2020, 10, 489. [CrossRef]

22. Cullity, B.D. Elements of X-Ray Diffraction; Addison-Wesly Publishing Co. Inc.: Singapore, 1976.

23. Sánchez-España, J.; Yusta, I. Coprecipitation of $\mathrm{Co}^{2+}, \mathrm{Ni}^{2+}$ and $\mathrm{Zn}^{2+}$ with $\mathrm{Mn}(\mathrm{III} / \mathrm{IV})$ Oxides Formed in Metal-Rich Mine Waters. Minerals 2019, 9, 226. [CrossRef]

24. Yu, J.; Yan, Q.; Chen, W.; Jain, A.; Neaton, J.B.; Persson, K.A. First-principles study of electronic structure and photocatalytic properties of $\mathrm{MnNiO}_{3}$ as an alkaline oxygen-evolution photocatalyst. Chem. Commun. 2015, 51, 2867-2870. [CrossRef] [PubMed] 
25. Ouaguenouni, M.H.S.; Benadda, A.; Kiennemann, A.; Barama, A. Preparation and catalytic activity of nickel-manganese oxide catalysts in the reaction of partial oxidation of methane. C. R. Chim. 2009, 12, 740-747. [CrossRef]

26. Waldron, R.D. Infrared Spectra of Ferrites. Phys. Rev. 1955, 99, 1725-1727. [CrossRef]

27. Berchmans, L.J.; Sevan, R.K.; Kumar, P.N.S.; Augustin, C.O. Structural and electrical properties of $\mathrm{Ni}_{1-x} \mathrm{Mg}_{x} \mathrm{Fe}_{2} \mathrm{O}_{4}$ synthesized by citrate gel process. J. Magn. Magn. Mater. 2004, 279, 103-110. [CrossRef]

28. Nakamoto, K. Infrared and Raman Spectra of Inorganic and Coordination Compounds; John Wiley and Sons, Ltd.: Hoboken, NJ, USA, 1986.

29. Jokanović, V.; Izvonar, D.; Dramićanin, M.D.; Jokanović, B.; Živojinović, V.; Marković, D.; Dačić, B. Hydrothermal synthesis and nanostructure of carbonated calcium hydroxyapatite. J. Mater. Sci. Mater. Med. 2006, 17, 539-546. [CrossRef]

30. Kaniyoor, A.; Baby, T.T.; Ramaprabhu, S. Graphene synthesis via hydrogen induced low temperature exfoliation of graphite oxide. J. Mater. Chem. 2010, 20, 8467-8469. [CrossRef]

31. Kloprogge, J.T.; Hickey, L.; Forst, R.L. FT-Raman and FT-IR spectroscopic study of synthetic Mg/Zn/Al-hydrotalcites. J. Raman Spectrosc. 2004, 35, 967-974. [CrossRef]

32. Wickham, D.G.J. Solid-phase equilibria in the system $\mathrm{NiO}-\mathrm{Mn}_{2} \mathrm{O}_{3}-\mathrm{O}_{2}$. Inorg. Nucl. Chem. 1964, 26, 1369-1377. [CrossRef]

33. Shahjahan, M.; Talukder, S.M.; Hossain, M.S.; Begum, M.H.A.; Warnock, R.L.; Haque, M.A.; Hossain, M.A.; Ahmed, N.A. Synthesis and Characterization of Structural and Electrical Properties of $\mathrm{Mg}_{0.25 x} \mathrm{Cu}_{0.25 x} \mathrm{Zn}_{1-0.5 x} \mathrm{Fe}_{2} \mathrm{O}_{4}$ Ferrites by sol Gel Method. Ukr. J. Phys. 2019, 64, 861-869. [CrossRef]

34. Deraz, N.M.; Shaban, S. Optimization of catalytic, surface and magnetic properties of nanocrystalline manganese ferrite. J. Anal. Appl. Pyrol. 2009, 86, 173-179. [CrossRef]

35. Hem, J.D.; Lind, C.J.; Roberson, C.E. Coprecipitation mechanisms and products in manganese oxidation in the presence of cadmium. Geochim. Cosmochim. Acta 1989, 53, 2435-2451. [CrossRef]

36. Alarifi, A.; Deraz, N.M.; Shaban, S. Structural, morphological and magnetic properties of $\mathrm{NiFe}_{2} \mathrm{O}_{4}$ nano-particles. J. Alloy. Compd. 2009, 486, 501-506. [CrossRef]

37. Macklen, E.D. Electrical conductivity and cation distribution in nickel manganite. J. Phys. Chem. Solids 1986, 11, 1073-1079. [CrossRef]

38. Devale, A.B.; Kulkarni, D.K. Structural, electrical and X-ray spectroscopic investigations of $\mathrm{MnNi}_{2} \mathrm{O}_{4}$ spinel. J. Phys. C Solid State Phys. 1982, 15, 899-905. [CrossRef]

39. Jung, H.R.; Lee, S.G.; Kim, K.M.; Kwon, M.S.; Kim, Y.G. Preparation and electrical properties of nickel manganite $\mathrm{Ni}_{0.79} \mathrm{Mn}_{2.21} \mathrm{O}_{4}$ ceramics for NTC thermistors. J. Ceram. Process. Res. 2017, 18, 357-360.

40. Mays, C.W.; Vermaak, J.S.; Wilsdorf, D.K. On surface stress and surface tension: II. Determination of the surface stress of gold. Surf. Sci. 1968, 12, 134-140. [CrossRef]

41. Tsunekawa, S.; Sahara, R.; Kawazoe, Y.; Ishikawa, K. Lattice relaxation of monosize $\mathrm{CeO}_{2-\mathrm{x}}$ nanocrystalline particles. Appl. Surf. Sci. 1999, 152, 53-56. [CrossRef]

42. Tsunekawa, S.; Ishikawa, K.; Li, Z.Q.; Kawazoe, Y.; Kasuya, Y. Origin of anomalous lattice expansion in oxide nanoparticles. Phys. Rev. Lett. 2000, 85, 3440-3443. [CrossRef]

43. Sun, C.; Li, H.; Chen, L. Nanostructured ceria-based materials: Synthesis, properties, and applications. Energy Environ. Sci. 2012, 5, 8475-8505. [CrossRef]

44. Mai, H.; Sun, D.; Zhang, Y.; Si, R.; Feng, W.; Zhang, H.; Liu, H.; Yan, C. Shape-selective synthesis and oxygen storage behavior of ceria nanopolyhedra, nanorods, and nanocubes. J. Phys. Chem. B 2005, 109, 24380-24385. [CrossRef]

45. Kurian, M.; Kunjachan, C. Investigation of size dependency on lattice strain of nanoceria particles synthesized by wet chemical methods. Int. Nano. Lett. 2014, 4, 73-80. [CrossRef]

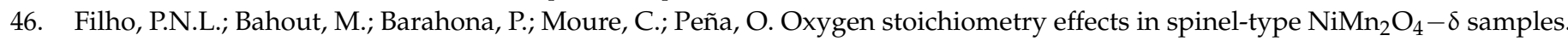
J. Phys. Chem. Solids 2005, 66, 1206-1212. [CrossRef]

47. Shen, Y.; Nakayama, T.; Arai, M.; Yanagisawa, O.; Izumi, M. Magnetic phase transition and physical properties of spinel-type nickel manganese oxide. J. Phys. Chem. Solids 2002, 63, 947-950. [CrossRef]

48. Savić, S.M.; Tadić, M.; Jagličić, Z.; Vojisavljević, K.; Mancić, L.; Branković, G. Structural, electrical and magnetic properties of nickel manganite obtained by a complex polymerization method. Ceram. Int. 2014, 40, 15515-15521. [CrossRef]

49. Yafet, Y.; Kittel, C. Antiferromagnetic Arrangements in Ferrites. Phys. Rev. 1952, 87, 290-294. [CrossRef]

50. Wang, J.; Gu, B.; Sang, H.; Ni, G.; Du, Y. Magnetocaloric effect in perovskite manganites $\mathrm{La}_{0.7-\mathrm{x}} \mathrm{Nd}_{\mathrm{x}} \mathrm{Ca}_{0.3} \mathrm{MnO}_{3}$ and $\mathrm{La}_{0.7} \mathrm{Ca}_{0.3} \mathrm{MnO}_{3}$. J. Magn. Magn. Mater. 2001, 223, 50-54. [CrossRef] 